\title{
Feasibility of innovative sharemilking arrangements
}

\author{
by Schröer-Merker, E. and Tozer, P.
}

Copyright, publisher and additional Information: This is the author's accepted manuscript. The final published version (version of record) is available online via Csiro Publishing

Please refer to any applicable terms of use of the publisher.

DOI: https://doi.org/10.1071/AN18530

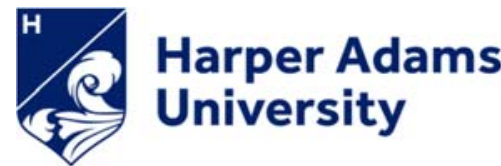

Schröer-Merker, E. and Tozer, P. 2019. Feasibility of innovative sharemilking arrangements. Animal Production Sciencel. 


\section{IIII! ANIMAL PRODUCTION SCIENCE}

\section{Feasibility of innovative sharemilking arrangements}

\begin{tabular}{|r|l|}
\hline Journal: & Animal Production Science \\
\hline Manuscript ID & Draft \\
\hline Manuscript Type: & Research paper \\
\hline Date Submitted by the Author: & n/a \\
\hline Complete List of Authors: & $\begin{array}{l}\text { Schröer-Merker, Eva; Massey University - Manawatu Campus, School of } \\
\text { Agriculture and Environment } \\
\text { Tozer, Peter; Massey University - Manawatu Campus }\end{array}$ \\
\hline Keyword: & $\begin{array}{l}\text { Dairy, Sustainable agriculture, Economics, Farm management, Decision } \\
\text { making }\end{array}$ \\
\hline \multicolumn{2}{|l}{} \\
\hline
\end{tabular}

SCHOLARONE ${ }^{m}$

Manuscripts 


\section{Feasibility of innovative sharemilking arrangements}

\section{Short title: Innovative sharemilking arrangements}

3 Eva Schröer-Merker ${ }^{1}$, Peter Tozer ${ }^{1}$

$4 \quad{ }^{1}$ School of Agriculture and Environment, Massey University

Contact:

Email: E.Schroer-Merker@massey.ac.nz

8

Email: p.tozer@massey.ac.nz

9

${ }^{1}$ C/- Massey University | PN433 | Private Bag 11-222 | Palmerston North 4442 | New Zealand

10 


\section{Summary text for the Table of Contents}

12

13

14

15

16

Sharemilking is an entry point for new dairy producers in the New Zealand industry, but growing milk price volatility increases the business risks for sharemilkers. We tested the hypothesis that flexible sharemilking arrangements will reduce the income variability of sharemilkers. The results illustrated the feasibility of a flexible model which shifts some of the risk from the sharemilker to the farm owner, while still allowing both to generate a positive ROA and a positive net profit with high probability. 
Abstract.

Sharemilking is an entry point for new dairy producers in the New Zealand industry, and traditionally most sharemilking arrangements have been a 50/50 arrangement. These structures are relatively rigid in the share of milk income and apportionment of operating costs between the land owner and sharemilker. With milk price volatility rising these types of arrangements increase the financial and business risks, particularly for sharemilkers. These risks are further compounded because the value of the primary asset owned by sharemilkers, cows, declines to a much greater extent than land with a fall in milk price, reducing total wealth. We tested the hypothesis that flexible sharemilking arrangements will reduce the variability of income of sharemilkers, making for a sustainable income pattern.

A synthesised dairy farm system is used to compare an innovative arrangement where milk revenue is divided based on milk payout price, rather than simply on contribution. Stochasticity is incorporated into the model to capture milk price volatility through the use of a stochastic price simulator. This approach allows decision rules to be built into the model based on revenue sharing to reduce income variability.

The identified innovative structures could be used by new entrants, sharemilkers, and land owners to encourage alternative forms of sharemilking revenue sharing, and provide information and education to the dairy industry. These alternative structures could be beneficial to industry sustainability, given that the dairy industry contributes a significant amount to New Zealand's economy and export earnings, and price volatility is expected to continue to increase.

Additional keywords: Sharemilking, income volatility, dairy, sustainable, risk, net profit, resilience

\section{Introduction}

Sharemilking is a widespread structure in New Zealand, where sharemilkers can use the milking plant and land, but provide labour and other specified inputs in return for a specified share of the milk price. The milk price share and inputs depend on the type of sharemilking agreement: 50/50 if they are herd-owning sharemilkers (HOSM), less if they are lower-order or variable order sharemilkers (VOSM). Variable-order sharemilkers are covered by the Sharemilking Agreements Order 2011, based on the Sharemilking Agreements Act of 1937 (Parliamentary Counsel Office, 2011), however HOSM are not covered by any specific legislation, but are considered as contractors and as such are covered by contract law. Sharemilking in New Zealand has been 
viewed as the typical pathway to farm ownership in the past (Gardner and Shadbolt 2005). In the 2016-17 production year, there were 8,508 owner operator herds and 3,203 herd owning sharemilker herds in New Zealand (DairyNZ 2018).

Previous research has identified that profitability for sharemilkers is highly variable due to milk price fluctuations (Gardner, 2005; Pepper, 2013), this variability can also be observed in Figure 1. With increased volatility in world commodity prices and the New Zealand dairy industry exporting over $90 \%$ of its product to world markets (Hemme (ed.), 2016), this structure has increasingly come under pressure and achieving farm ownership more unlikely. New developments, such as Mycoplasma bovis, have further intensified the pressure on sharemilkers (Vance, 2018). In periods of low milk prices, sharemilkers, HOSM and VOSM, come under stress to break even financially. Furthermore, the situation for the HOSM is further aggravated as their wealth decreases due to lower livestock values. This is reflected in the number of herds milked by each group: while the average number of dairy herds in the period $2009 / 10$ to $2016 / 17$ was 11,800 , the number of herds milked by owner operators increased $13 \%(7,534$ to 8,508$)$ and the number of herds milked by sharemilkers fell by $22 \%(4,125$ to 3,203$)$ in the same time period (DairyNZ, various).

Figure 1 Operating profit for herd-owning sharemilkers (SM) and owner operators (OOP) for production years 2007-08 to 2016-17 (data DairyNZ, various)

Albeit, or despite, being an omnipresent system in New Zealand, research and publications on sharemilking are scarce. Currently the industry, namely DairyNZ and Federated Farmers, are looking into alternative options, one of them being a 'flexi-rate', where a low milk price triggers a contract/salary option. After realizing that there is a lack of understanding of alternative options, and a fair degree of caution amongst all parties about undertaking these options, DairyNZ and MyFarm began examining the concept of Flexi-Rate sharemilking (DairyNZ, nd). We identified two potential alternatives: First, income insurance similar to the Crop and Revenue insurance (OECD, 2000), or the Livestock Gross Margin Insurance for Dairy Cattle (LGMDairy), which "is a risk management tool for protecting milk income over feed cost margins" (Bozic et al., 2014). The main characteristic of income insurance, as with all insurance markets, is a pooling of risk (OECD, 2000). Both income insurance types are commonly used in the USA. Second, and potentially more suitable to the sharemilking system prevalent in Australia and New Zealand, is a more flexible arrangement in the split of 
income between sharemilker and farm owner, on a mutually agreeable basis rather than rigidly set as is now common. In contrast to the insurance system, the latter alternative does not change the mean income of any given farm, but instead is flexible in its allocation to the parties involved. The objective of this study was to study the economic feasibility of the second option and to provide quantitative results on its impact on sharemilkers and landowners.

\section{Methods}

A cash budget was designed to measure the income and expenses of a HOSM and landowner. The present research uses the software @Risk, which uses Monte Carlo simulation to construct probability distributions of variables of interest (Palisade, 2018). This stochasticity is designed to capture milk price volatility through the use of a stochastic price simulation. A synthesised dairy farm system (base system), was developed. The base system is a 550 cow pasture-based system, reflective of System 2 or System 3 (DairyNZ, 2017). Knowledge of cost and revenue sharing was used to develop financial information for owner operators and sharemilkers under "standard" (50/50) sharemilking agreements. This base system was used to compare to an innovative arrangement where milk revenue is divided based on milk payout price, rather than simply on contribution.

The model required inputs and outputs, and the number of iterations set. Stochastic input variables were: milk price, cow price, supplementary feed expenses per cow, and urea expenditure for the enterprise. Historic milk price data (DairyNZ various) was used, and cow price data was from the Inland Revenue Department (IRD, 2018). Prices were adjusted to correct for inflation using the agriculture producer price index (PPI) (StatsNZ, 2018).

For input variables, the distribution used was determined using statistical fit analysis, such as the Akaike Information Criteria (AIC) - normal, lognormal, or triangular - as well as the arithmetic mean and standard deviation, which were drawn from the data (

Table 1). A lognormal distribution was identified for the milk price and simulation of the distribution yielded a \$NZ 4.95 to \$NZ 8.93 as the 90th percentile range. The distribution was skewed to the left with a median of \$NZ 5.92 compared to the mean of \$NZ 6.23 and a standard deviation of \$NZ 1.43. Cow price (mixed age) was normally distributed, with a 90\% probability range between \$NZ 1,304 and \$NZ 2,282 per cow, mean of \$NZ 1,725 , and standard deviation of \$NZ 300. Supplementary feed expenses per cow were normally distributed, 
with a 90 percentile range of \$NZ 159 and \$NZ 259, a mean of \$NZ 209, and a standard deviation of approximately \$NZ 30. Urea expenses for the enterprise were defined by a triangular distribution, with minimum $\$ N Z 46,000$, maximum $\$ N Z 84,858$, and most likely value of $\$ N Z 53,095$. The variation in feed and urea expenses were due to price variation, input levels remained constant. Milk production remained constant.

Table 1: Specifications of input variables

Return on assets (ROA) was identified as a key output, as it reflects the effect of milk price volatility and changing asset value (cows). Other key outputs were cash surplus (or deficit) and net profit (or loss). The @Risk simulation was set to 10,000 iterations.

Flexible model

The base model was then modified to allow for a more flexible allocation of milk revenue between farm owner and HOSM. A constraint was entered into the model to change the 50/50 base-allocation to the following: If milk prices dropped below \$NZ 4.59 per kg milk solid, the HOSM was allocated a larger share (60\%) of milk revenues, while the remaining $40 \%$ was allocated to the farm owner. If the milk price was above $\$ N Z 8.93$ per kg milk solid, the adjusted shares were reversed, the farm owner receiving $60 \%$ and the HOSM $40 \%$. The milk price bounds were set according to ranges shown in

Table 1, representing the 90 percentile range. Cost split remained constant in both scenarios.

\section{Results}

Base model

Table $\mathbf{2}$ shows the detailed results for the three output variables according to the standard revenue split between farm owner and HOSM in the base system. It shows that while cash surplus tends to be higher for the HOSM, average net profits are higher for the farm owner, it is skewed with a relatively high probability of being negative for the $\operatorname{HOSM}(7.2 \%)$ and a median of $\$ N Z 107,682$, due to the impact of the log-normally 

higher).

Table 2: Detailed results for the three output variables, for farm owner and HOSM - Base model

The base system, under a standard sharemilking agreement, showed that the HOSM is facing a higher probability of low returns compared to the farm owner (

Table 2). The results showed no cash deficits for HOSM, a mean of $\$ N Z 227,283$, and standard deviation of

\$NZ 136,928, while farm owners were faced with a $1.5 \%$ chance of a cash deficit with a mean of $\$ N Z 186,390$ and standard deviation of \$NZ 140,424.

Table 3: Probability of results being zero or negative - Base model

The range of ROA was generally wider for HOSM, with a mean of $8.6 \%$ and standard deviation of $5.5 \%$, as HOSM have a lower asset base compared to the farm owner. Farm owners, in comparison, have an average ROA of $4.2 \%$ with a standard deviation of $1.9 \%$.

Negative net profit occurred in $7.2 \%$ of the iterations for the HOSM, in comparison to $0.1 \%$ for the farm owner. As can be seen in Figure 2, the HOSM not only faces a higher probability of negative results, but also has a higher probability of low positive net profit compared to the farm owner. For the HOSM, the results showed a mean of $\$ N Z 137,631$ (standard deviation $\$ N Z 130,040$ ), while results for farm owners were 58\% higher with a mean of \$NZ 216,975 (standard deviation \$NZ 140,424).

Figure 2: Net profit distribution for HOSM and farm owner - Base model

Flexible model

The detailed results in

Table 4 show the effect of the flexible sharemilking arrangement in contrast to the $50 / 50$ base model as shown in 
Table 2. For the HOSM, the probability of low financial results is reduced, while the probability of very high financial returns is also curtailed, indicating a narrower range. In contrast, farm owners have a higher probability of lower results under the flexible arrangement, while also increasing the probability of high results, indicating an increase in the range of returns to farm owners.

Table 4: Detailed results for the three output variables, for farm owner and HOSM - Flexible model

This reallocation of returns and profits was achieved with little impact on the mean $(\$ N Z-5,850$ and $+5,838)$ and median (\$NZ +490 and $+4,137)$. Standard deviation was consistently reduced for the HOSM, while it increased for the farm owner. This is important as the goal of this study was to show that a reallocation of milk income between farm owner and HOSM is possible and feasible, without significantly altering the average total farm milk income per se.

The results showed an increase in the likelihood of a cash deficit for the farm owner (up 3.5 percentage points) as well as for a net loss (up 4.3 percentage points). This was contrasted by lower probabilities for negative results for the HOSM: down 0.2 percentage points to $0.01 \%$ for negative ROA and 4.3 percentage points down to $2.9 \%$ probability of net loss (

Table 5).

Table 5: Probability of results being zero or negative - Flexible model

\section{Discussion}

This research identified the impact of a modification to the common New Zealand 50/50 sharemilking model and showed how it reduced the downside risk for HOSM. The current sharemilking model has been in decline in recent years (DairyNZ, various), and while specific reasons for this trend may not be well understood, the high downside risk for HOSM has been discussed (Gardner, 2011; Pepper, 2013). The important factor in the current model was the ability to assess and quantify the risks associated with the current 50/50 and modified flexible sharemilking options (

\section{Table 3,}


Table 5). The results shown are for the most likely outcomes within the imposed changes over 10,000 iterations. Net profit is often defined as 'the bottom line', and with over $7.2 \%$ probability of it being negative in the base system, HOSM face considerable risk, especially as they do not have a substantial asset base to allow for sufficient borrowing. An aggravating factor is that frequently in downturn milk price cycles, cow prices also decrease, thus further lowering the asset base of the HOSM. The study has illustrated the possibility and feasibility of a flexible herd-owning sharemilking model which shifts some of the risk (upside as well as downside) from the sharemilker to the farm owner, while still allowing both parties to generate a positive ROA and a positive net profit with $95.6 \%$ to $97.1 \%$ probability (

\section{Table 4,}

Table 5). The same clarity of results would not be possible if the data from many farms were merged as $50 / 50$ sharemilking agreements are negotiated bilaterally and thus do not present a homogenous group with comparable inputs and cash budgets. Figure 3 illustrates how the probabilities for net profit are more compact for HOSM and farm owner in the flexible model compared to the base model (Figure 2).

\section{Figure 3: Net profit distribution for HOSM and farm owner - Flexible model}

While the farm owner has additional downside risk in the flexible model in low milk price seasons compared to the base model, the likelihood for high returns is also increased in case of high milk prices, due to the reverse distribution of milk income. The farmer's and sharemilker's attitude to risk, and credit availability will likely be main factors in the choice of such a model, as well as its specifications, especially the milk income distribution and the cut-off milk prices at which the flexible model is activated.

\section{Conclusion}

This approach allows decision rules to be built into the models based on revenue sharing to reduce income variability. While the study showed the general feasibility of flexible sharemilking agreements, we recommend building on the existing research by analyzing a range of 50/50 sharemilking cases as well as monthly cash-flow budgets. This could help to further fine-tune the cut-off milk price at which the allocation of milk income changes from the prescribed 50/50 arrangement as well as the percentages of the flexible arrangement. 
Bozic M, Newton J, Thraen C S, Gould B W (2014) Tails Curtailed: Accounting for Nonlinear Dependence in Pricing Margin Insurance for Dairy Farmers. American Journal of Agricultural Economics 96(4): 1117-1135; doi: 10.1093/ajae/aau033

DairyNZ (2017) Facts \& Figures - A quick reference guide for New Zealand dairy farmers. $2^{\text {nd }}$ Edition. Hamilton. DairyNZ (various) DairyNZ Economic Survey 2009/10 to 2016-17. Hamilton.

DairyNZ (n.d. - no date). Flexi-Rate Sharemilking agreement (concept). DairyNZ, Hamilton.

Gardner J W (2005) Lower order sharemilking in New Zealand. In Proceedings of the $15^{\text {th }}$ International Farm Management Conference. Campinas, Brazil.

Gardner J W (2011) Sharemilking in New Zealand. In Proceedings of the $18^{\text {th }}$ International Farm Management Conference. Methven, New Zealand.

Gardner J W, Shadbolt N (2005) Wealth creation. In: 'Farm Management in New Zealand' (Eds N. Shadbolt, S. Martin) pp267-304. (Oxford University Press: Melbourne)

Hemme T (ed.) (2016) IFCN Dairy Report 2016. IFCN, Kiel, Germany.

IRD (2018) National average market values of specified livestock determinations. Available at https://www.ird.govt.nz/technical-tax/determinations/livestock/national-averages/livestock-nat-aveindex.html [verified 22 August 2018]

Parliamentary Counsel Office (2011) Sharemilking Agreements Order 2011. Wellington. Available at http://www.legislation.govt.nz/regulation/public/2011/0295/7.0/DLM3950706.html [verified 18 August 2018] OECD (2000) Income Risk Management in Agriculture. OECD, Paris.

Palisade (2018) @Risk - Advanced Risk Analysis for Microsoft Excel and Project.

Pepper M (2013) What's wrong with the 50/50 Sharemilking contract! 'The decline of the Herd Owning Sharemilker'. Report for the Kellogg Rural Leadership Program. Christchurch. 
225 StatsNZ (2018) Producers Price Index - information releases Available at

226 http://archive.stats.govt.nz/browse_for_stats/economic_indicators/prices_indexes/producers-price-index-

227 info-releases.aspx [verified 22 August 2018]

228 Vance A (2018) Is it the end of sharemilking? Manawatu Standard, 25/05/2018. ISSN: 11763558

229

\section{Conflicts of Interest}

The authors declare no conflicts of interest.

Acknowledgements

234 This project was financed with a Massey University Research Fund (MURF) grant. Thanks to Angie Fisher

235 (DairyNZ) for providing supporting information and data. 


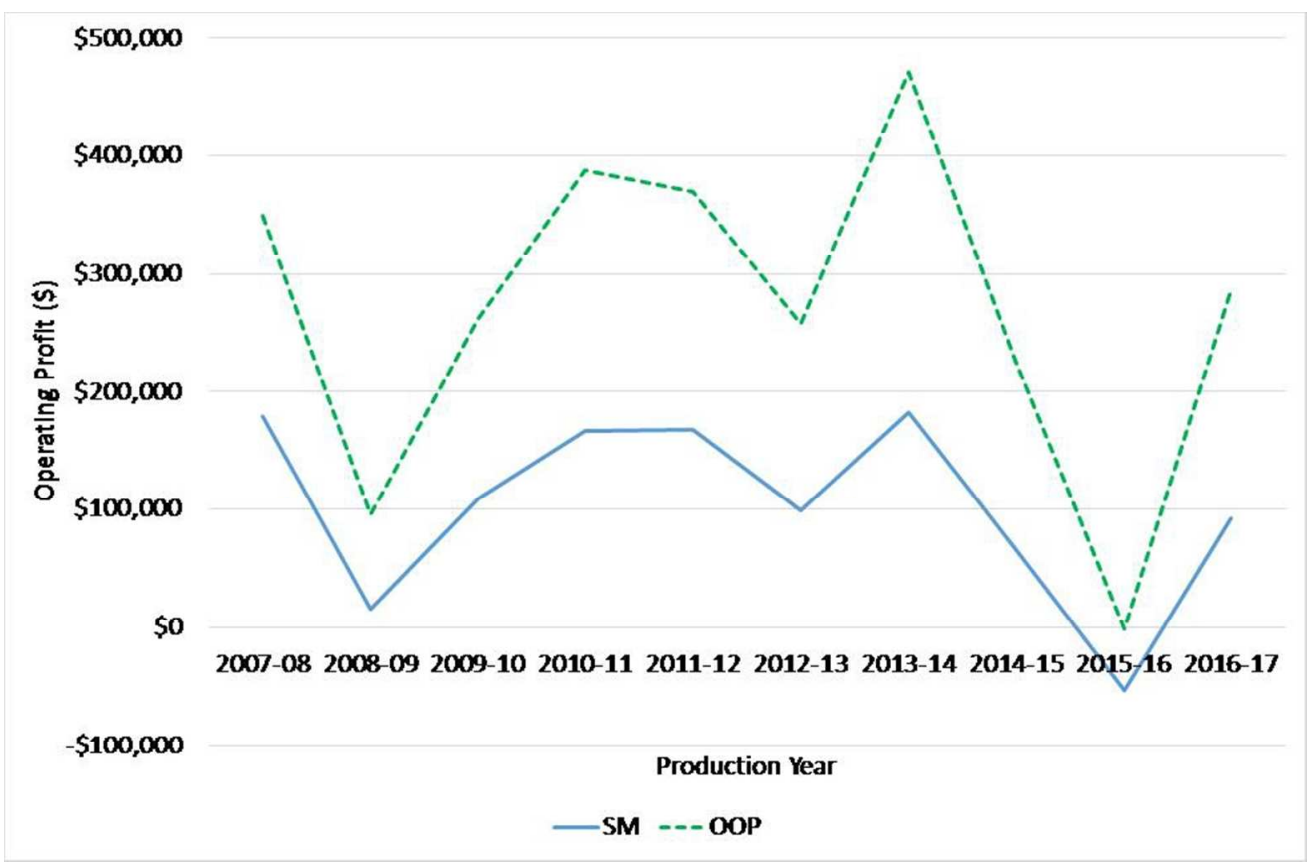

Figure 1 Operating profit for herd-owning sharemilkers (SM) and owner operators (OOP) for production years 2007-08 to 2016-17 (data DairyNZ, various)

$258 \times 169 \mathrm{~mm}(96 \times 96 \mathrm{DPI})$ 


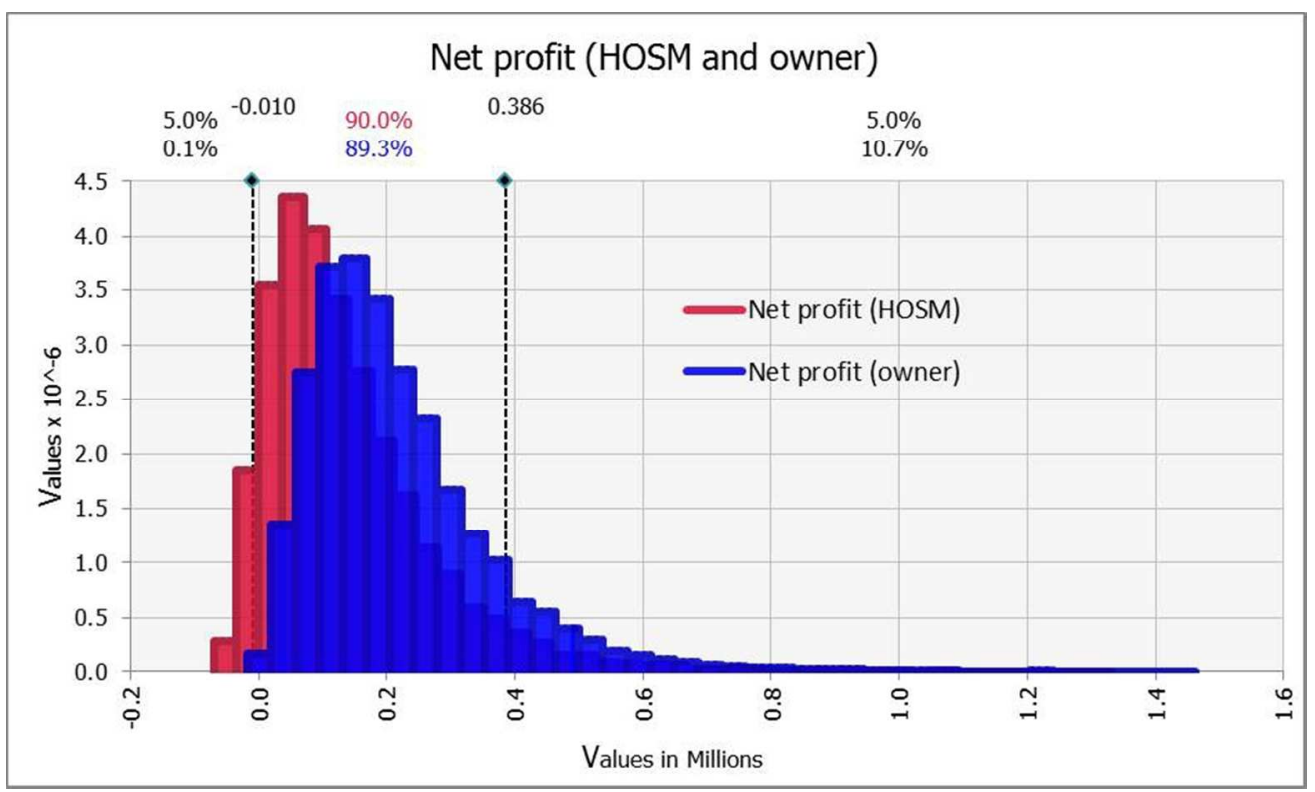

Figure 2 Net profit distribution for HOSM and farm owner - Base model

$159 \times 95 \mathrm{~mm}(150 \times 150 \mathrm{DPI})$ 


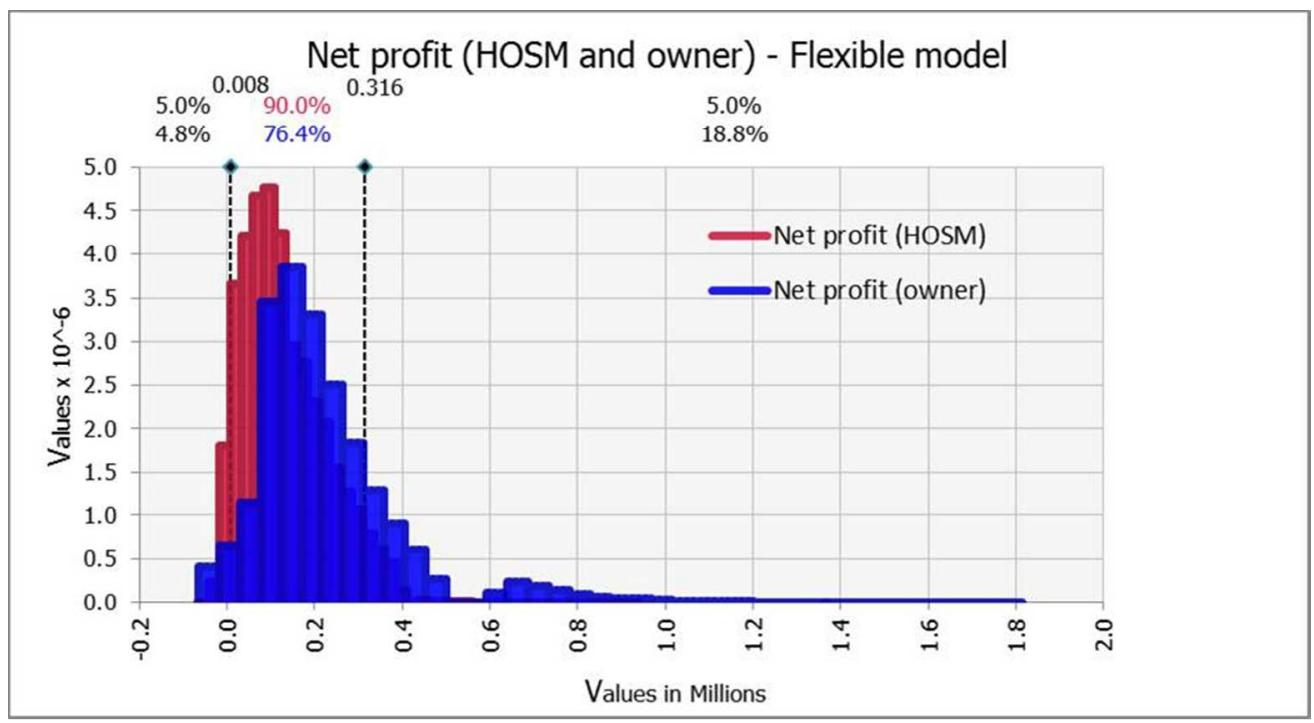

Figure 3 Net profit distribution for HOSM and farm owner - Flexible model $159 \times 87 \mathrm{~mm}(150 \times 150 \mathrm{DPI})$ 


\begin{tabular}{|l|c|cc|c|c|}
\hline & Distribution & $\begin{array}{c}\text { Range } \\
\text { (NZ \$), } \\
90 \% \\
\text { probability }\end{array}$ & $\begin{array}{c}\text { Mean } \\
\text { (NZ \$) }\end{array}$ & $\begin{array}{c}\text { Median } \\
\text { (NZ \$) }\end{array}$ & $\begin{array}{c}\text { Standard } \\
\text { deviation } \\
\text { (NZ \$) }\end{array}$ \\
\hline Milk price & Lognormal & $4.59-8.93$ & 6.23 & 5.92 & 1.43 \\
\hline Cow price & Normal & $\begin{array}{c}1,304- \\
2,282\end{array}$ & 1,750 & 1,725 & 300 \\
\hline $\begin{array}{l}\text { Supplement } \\
\text { expenses } \\
\text { per cow }\end{array}$ & Normal & $159-259$ & 209 & 209 & 31 \\
\hline $\begin{array}{l}\text { Urea } \\
\text { expenses } \\
\text { for the } \\
\text { enterprise }\end{array}$ & Triangular & $\begin{array}{c}49,685- \\
76,986\end{array}$ & 61,286 & 59,977 & 8,456 \\
\hline
\end{tabular}

Table 1 Specifications of input variables $108 \times 62 \mathrm{~mm}(150 \times 150 \mathrm{DPI})$ 


\begin{tabular}{|c|c|c|c|c|c|}
\hline & & $\begin{array}{c}\text { Range } \\
\text { (NZ \$), } \\
90 \% \\
\text { probability }\end{array}$ & $\begin{array}{l}\text { Mean } \\
\text { (NZ \$) }\end{array}$ & $\begin{array}{c}\text { Median } \\
\text { (NZ\$) }\end{array}$ & $\begin{array}{c}\text { Standard } \\
\text { deviation } \\
\text { (NZ \$) }\end{array}$ \\
\hline \multirow{2}{*}{$\begin{array}{l}\text { Cash } \\
\text { surplus } \\
\text { / } \\
\text { (deficit) }\end{array}$} & $\begin{array}{l}\text { Farm } \\
\text { owner }\end{array}$ & $\begin{array}{c}23,946- \\
452,486\end{array}$ & 186,390 & 155,438 & 140,424 \\
\hline & HOSM & $\begin{array}{l}70,039- \\
486,865\end{array}$ & 227,283 & 196,592 & 136,928 \\
\hline \multirow{2}{*}{$\begin{array}{l}\text { Net } \\
\text { profit / } \\
\text { (loss) }\end{array}$} & $\begin{array}{l}\text { Farm } \\
\text { owner }\end{array}$ & $\begin{array}{l}54,530- \\
483,070\end{array}$ & 216,975 & 186,022 & 140,424 \\
\hline & HOSM & $\begin{array}{c}(9,530)- \\
385,682\end{array}$ & 137,631 & 107,682 & 130,040 \\
\hline \multirow{2}{*}{$\begin{array}{l}\text { Return } \\
\text { on } \\
\text { assets } \\
\text { (in \%) }\end{array}$} & $\begin{array}{l}\text { Farm } \\
\text { owner }\end{array}$ & $\begin{array}{c}1.98- \\
7.76\end{array}$ & 4.17 & 3.76 & 1.89 \\
\hline & HOSM & $\begin{array}{c}1.90- \\
18.9\end{array}$ & 8.57 & 7.46 & 5.45 \\
\hline
\end{tabular}

Table 2 Detailed results for the three output variables, for farm owner and HOSM - Base model $96 \times 71 \mathrm{~mm}(150 \times 150 \mathrm{DPI})$ 


\begin{tabular}{|l|c|c|c|}
\hline & $\begin{array}{c}\text { Cash } \\
\text { surplus }\end{array}$ & $\begin{array}{c}\text { Return on } \\
\text { assets }\end{array}$ & Net profit \\
\hline HOSM & $0.0 \%$ & $0.2 \%$ & $7.2 \%$ \\
\hline $\begin{array}{l}\text { Farm } \\
\text { owner }\end{array}$ & $1.5 \%$ & $0.0 \%$ & $0.1 \%$ \\
\hline
\end{tabular}

Table 3 Probability of results being zero or negative - Base model $81 \times 23 \mathrm{~mm}(150 \times 150 \mathrm{DPI})$ 


\begin{tabular}{|l|l|l|l|l|l|}
\hline & & $\begin{array}{l}\text { Range } \\
\text { (\$NZ), } \\
90 \% \\
\text { probability }\end{array}$ & $\begin{array}{l}\text { Mean } \\
\text { (\$NZ) }\end{array}$ & $\begin{array}{l}\text { Median } \\
\text { (\$NZ) }\end{array}$ & $\begin{array}{l}\text { Standard } \\
\text { deviation } \\
\text { (\$NZ) }\end{array}$ \\
\hline $\begin{array}{l}\text { Cash } \\
\text { surplus } \\
\text { / } \\
\text { (deficit) }\end{array}$ & $\begin{array}{l}\text { Farm } \\
\text { owner }\end{array}$ & $\begin{array}{c}5,772- \\
576,266\end{array}$ & 192,229 & 155,928 & 171,336 \\
\cline { 2 - 6 } & HOSM & $\begin{array}{l}90,277- \\
417,582\end{array}$ & 221,434 & 197,965 & 102,834 \\
\hline $\begin{array}{l}\text { Net } \\
\text { profit / } \\
\text { (loss) }\end{array}$ & $\begin{array}{l}\text { Farm } \\
\text { owner }\end{array}$ & $\begin{array}{c}36,356- \\
606,850\end{array}$ & 222,813 & 186,512 & 171,336 \\
\cline { 2 - 6 } $\begin{array}{l}\text { Return } \\
\text { on } \\
\text { assets } \\
\text { (in \%) }\end{array}$ & $\begin{array}{l}\text { Farm } \\
\text { owner }\end{array}$ & $\begin{array}{c}8,458- \\
315,965\end{array}$ & $131,76-$ & 111,819 & 96,616 \\
\cline { 2 - 6 } & HOSM & $\begin{array}{l}2.85- \\
16.16\end{array}$ & 8.25 & 3.76 & 2.31 \\
\hline
\end{tabular}

Table 4 Detailed results for the three output variables, for farm owner and HOSM - Flexible model $97 \times 75 \mathrm{~mm}(150 \times 150 \mathrm{DPI})$ 


\begin{tabular}{|l|c|c|c|}
\hline & $\begin{array}{c}\text { Cash } \\
\text { surplus }\end{array}$ & $\begin{array}{c}\text { Return on } \\
\text { assets }\end{array}$ & Net profit \\
\hline HOSM & $0.0 \%$ & $0.01 \%$ & $2.9 \%$ \\
\hline $\begin{array}{l}\text { Farm } \\
\text { owner }\end{array}$ & $5.0 \%$ & $0.0 \%$ & $4.4 \%$ \\
\hline
\end{tabular}

Table 5 Probability of results being zero or negative - Flexible model

$84 \times 29 m m(150 \times 150$ DPI $)$ 